\title{
Analysing a Bottom-up Methodology for Developing Communal Biogas Plants in Croatia
}

\author{
Mak Đukan*1, Zoran Aralica ${ }^{2}$ \\ ${ }^{1}$ Wegener Center for Climate and Global Change, Karl-Franzens University of Graz, Brandhofgasse 5, \\ Graz, Austria \\ e-mail: mak.dukan@gmail.com \\ ${ }^{2}$ The Institute of Economics, J. F. Kennedy Square 7, Zagreb, Croatia \\ e-mail: zaralica@eizg.hr
}

Cite as: Đukan, M., Aralica, Z., Analysing a Bottom-up Methodology for Developing Communal Biogas Plants in Croatia, J. sustain. dev. energy water environ. syst., 3(4), pp 359-371, 2015, DOI: http://dx.doi.org/10.13044/j.sdewes.2015.03.0027

\begin{abstract}
This research presents a bottom-up methodology for assessing biogas potentials applied in a local community in Croatia. The research is based on analysing the flow of resources on a local level and capability of local actors to innovate and cooperate. Our method grades the local actors - in this case, owners of family farms in Gundinci municipality in Croatia based on their farms' biogas potential (or the amount and quality of manure they produce) and an indicator which we refer to as innovative-cooperation capacity. This methodology builds upon the biogas potential analysis by identifying farmers who are willing to improve their farms manure management system and cooperate in the field of biogas production in Gundinci. The replication of this methodology could stimulate rural development, through pinpointing realizable biogas projects, which could generate new money flows for the local economies and help farmers meet the norms of the European Union Nitrates Directive which regulates manure management, in order to control nitrogen flows in agriculture.
\end{abstract}

\section{KEYWORDS}

Biogas potential analysis, Innovative-cooperation capacity, Rural development.

\section{INTRODUCTION}

Current studies on biogas potentials in Croatia have largely been top-down and have relied on attributing biogas yields to all statistically recorded animals. While Kulišić and Par (2009) [1] and Kralik (2012) [2] use as their main data source the latest Agricultural Census, Pukšec and Duić (2010) [3] rely on a pig and beef overview from the Croatian Agricultural Agency. In this paper we argue that such studies are overly simplistic, because they rely on averages that fail to capture regional biogas hot spots or locations that overshoot the average number of animals attributed to that region.

The present approach of biogas potentials analysis simplifies systems wherein biogas plants are developed, through ignoring the complexities of interactions between their individual segments. For instance, human interactions between stakeholders are not taken into account. Analysed systems are in fact complex and characterized by non-linear interacting relationships within social, economic, legal and cultural dimensions [4]. Regarding this, a biogas project is only viable, as much as the willingness of the local community to cooperate with a biogas developer and with each other.

\footnotetext{
* Corresponding author
} 
Instead of the above-described top-down approach we propose a bottom-up method for analysing local biogas potentials. The methodology consists of analysing the farmer's material and energy flows and innovative-cooperation capacity, after which the economic potential and feasibility of a sought plant is evaluated. This is done through a standard cash flow analysis, which produces the project's Internal Rate of Return (IRR). Our methodology was tested in Gundinci municipality, which is located in one of the least developed regions of Croatia [5] and has historically been mostly agricultural. This methodology has not yet been applied in Croatia, and to the best of our knowledge we have not encountered any literature that introduces the innovative-cooperation analysis of local actors.

The results indicate the availability of $31,000 \mathrm{t}$ of different kinds of animal manure in Gundinci, with an energy value that is double the yearly electricity consumption of the municipality. Through applying our methodology we excluded $13 \%$ of the originally located manure, since this is originating from farms with little innovative and cooperative capacity and/or small biogas potential. After this we modelled the economics of a potential biogas project, using the leftover manure and 13,500 t of corn silage. Based on our analysis, the plant would have an IRR of $16 \%$, which varies with changes in input variables and is mostly sensitive to changes in investment costs.

The paper first discusses the applicability of the proposed bottom-up approach in developing biogas projects and provides a comparison with the conventional statistics-based potentials analysis. After describing our methodology and data, we discuss the economics of a potential biogas plant in Gundinci. Finally we provide concluding remarks.

\section{THE BOTTOM-UP ANALYSIS OF BIOGAS PRODUCTION POTENTIALS}

The intricacy of material and energy systems requires an approach to potentials analysis that takes into account system complexity and focuses on satisfying local environmental, social and economic needs. This necessitates taking a bottom-up approach for the analysis, where a particular project location is viewed within the sphere of local material and energy flows and the innovative-cooperation potential of the local population. Other attempts to analyse the local biogas potential focused mainly on biogas feedstock and its energy value as mentioned above.

The bottom-up approach is suitable for locations where local communities initialize biogas projects themselves (e.g., village). In this way rural and small-scale energy needs could be met in a reliable, affordable and environmentally sustainable way [6]. However, this approach also highlights contextual and demand-side issues and may stimulate easier technology acceptance. This could also enable development of community-focused financing schemes to improve the affordability of biogas systems [7]. In terms of cooperation, our approach is similar to that of Mallet [8] who asserts that active interaction between participants from various sectors increases social acceptance of renewable energy innovations.

Our analysis seeks to understand the innovative-cooperation capacity of local actors. This includes the analysis of the near future innovation performance of the actors in a specific location and their willingness to cooperate [9]. We define innovative capacity as an ability of conducting innovation activities with innovation output variables i.e. innovation products and/or processes as the visible results of innovation inputs i.e. innovation investments [10]. Their innovative capacity is determined through examining elements of the farmer's (dynamic) development over time, such as their number of animals and land under cultivation and investments into private land and manure management systems, with the aim of producing new products and/or services. On the 
other hand, the farmer's cooperation capacity is determined through their willingness to supply manure, grow energy crops and invest jointly into a communal biogas plant.

The advantages of the bottom-up approach over the conventional (top-down) approach of biogas potential analysis are presented below (Table 1).

Table 1. Comparison of conventional and bottom-up approach in biogas potentials analysis

\begin{tabular}{|c|c|}
\hline Conventional approach & Bottom up approach \\
\hline Simplistic approach & Embraces complexity \\
\hline $\begin{array}{c}\text { Decision making is guided by statistical } \\
\text { averages }\end{array}$ & $\begin{array}{l}\text { Decision making based on location } \\
\text { specific material and energy flows }\end{array}$ \\
\hline $\begin{array}{c}\text { Calculates the biogas potential based on } \\
\text { the entire location specific amount of } \\
\text { feedstock }\end{array}$ & $\begin{array}{l}\text { Calculates the biogas potential based on } \\
\text { the feedstock from farmers with } \\
\text { innovative-cooperation potential }\end{array}$ \\
\hline $\begin{array}{l}\text { Includes as feedstock only the available } \\
\text { manure }\end{array}$ & $\begin{array}{l}\text { Includes as feedstock all available } \\
\text { organic materials on site that are } \\
\text { economically usable }\end{array}$ \\
\hline $\begin{array}{l}\text { Takes into account the techno-ec } \\
\text { aspects of developing a biogas }\end{array}$ & $\begin{array}{l}\text { Takes into account the techno-economic } \\
\text { and human aspects through analysing } \\
\text { local stakeholders }\end{array}$ \\
\hline $\begin{array}{l}\text { Oriented towards achieving the greatest } \\
\text { economic returns }\end{array}$ & $\begin{array}{l}\text { Oriented towards achieving the most } \\
\text { sustainable outcome in terms of } \\
\text { economic, social and environmental goals }\end{array}$ \\
\hline $\begin{array}{r}\text { Derives conclusion } \\
\text { available }\end{array}$ & $\begin{array}{c}\text { Derives conclusions from local } \\
\text { knowledge }\end{array}$ \\
\hline
\end{tabular}

\section{METHODOLOGY AND DATA}

Our methodology analyses three basic aspects that make a biogas project viable:

- Local material and energy flows;

- Farmers innovative-cooperation capacity;

- Economic and technical feasibility of the project.

The availability of suitable feedstock for conversion into biogas is the first aspect in determining the local biogas potential. However, this information is useless without knowing if local farmers would be willing to supply a biogas plant with manure. Finally, we need to consider if the determined biogas potential can be converted economically into energy. This largely depends on the amount of energy potential, where the feasibility improves with the project's size. Determining basic financial parameters like IRR defines if a bankable project can be developed.

Data was collected through forty-three structured interviews with family farm owners and households. This was chosen over other methods - like questionnaires - because the data is complete and recovered immediately. Moreover, the interviewer can guide the respondent during the talk, which assures accuracy. Additional information, outside the structured questions can also be gathered. We also conducted a semi-structured interview with the mayor who provided us with data such as number of households and farms in the municipality and local waste management system.

The structured interview consisted of forty questions that were subdivided into main categories as presented in Figure 1. Apart from manure quantities and source, which was the base for Material Flow analysis, the interviews assessed the farms in terms of the size, ownership and use of land holdings, quality of manure management system and speed 
with which they increased the number of animals and land under cultivation in the past five years and ambition for future development. These questions were aimed at evaluating their innovative capacity or capability to grow their business. Finally we investigated the farmer's willingness to supply manure, grow energy crops and invest into a biogas project in their community, which we used to evaluate their cooperation capacity. Altogether, these qualitative aspects of our assessment make what we term innovative-cooperation capacity (for more detail, please see the second step of the methodology).

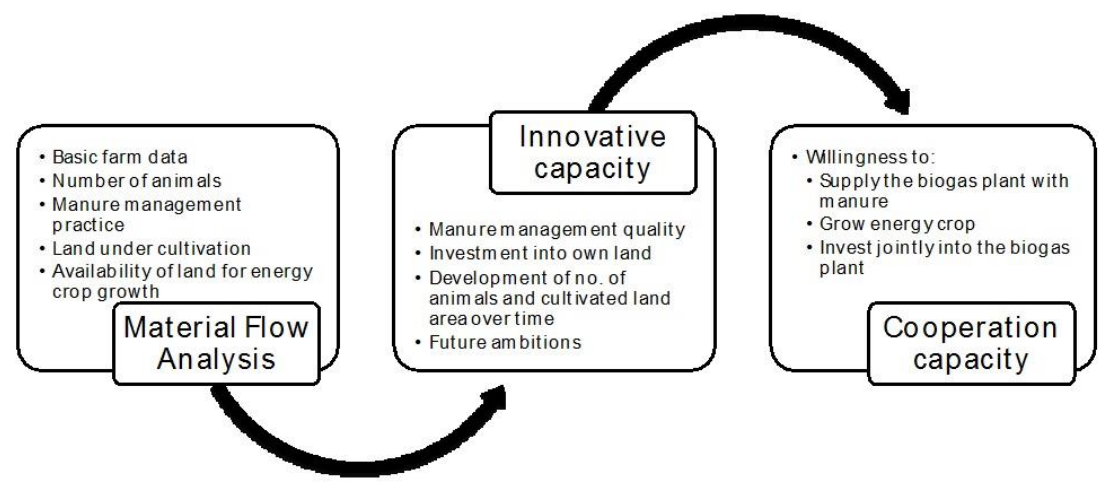

Figure 1. Contents of the structured interviews

Therefore, the first step of our methodology determines the amount of material and energy flows arising in Gundinci municipality. Initial desktop research and interviews with the mayor and community members revealed two main waste flows, suitable for biogas production:

- Agricultural waste including animal manure and dead animals;

- Municipal solid waste.

Municipal solid waste was excluded from further analysis because only $345 \mathrm{t}$ [11] are produced per year and this has a relatively low organic content. Namely, the locals use their food waste as animal feed or compost. Dead animals that could be used for biogas production - after treatment and sterilization - were also excluded because they are collected and processed into technical fat. Therefore, the focus of our material and energy flow analysis was animal manure.

Table 2 shows the data sample (obtained through a semi-structured interview with the mayor of Gundinci), which consists of thirty-three family farms and ten households and small farms. Big family farms (more than 50 livestock units) constitute the majority of the sample and among these $43 \%$ were cattle farms, $31 \%$ pig fattening facilities and $26 \%$ broiler fattening operations. Unlike the big family farms that were targeted through the help of our semi-structured interviews, households and small farms were chosen randomly.

The animal numbers that were obtained were converted into Livestock Units $(L U)^{\dagger}$ using standardized conversion rates [12]. The $L U$ 's were then multiplied with yearly manure production estimates, which were obtained through literature review [13].

The data quality was crosschecked by comparing the animal numbers obtained through the research, with the official Croatian Agricultural Agency data on total municipal animal numbers, for the period between 2010 and 2012. There is a divergence with official data, since the number of broiler and pig livestock units surveyed is $279 \%$ and $247 \%$ higher. Considering this, another field visit was arranged and this included

${ }^{\dagger} 1 L U$ equals $500 \mathrm{~kg}$ worth of animal mass. 
$95 \%$ of originally recorded pig and $79 \%$ broiler $L U$. Little variation was found from the original data, as pig farmers reported $7.2 \%$ less animal numbers than the first time, while there were also $2.1 \%$ fewer broilers recorded [13]. This confirmed that the official statistics greatly diverge from the real ground situation, justifying the need for research of this type.

Table 2. Data sample coverage rate

\begin{tabular}{cccc}
\hline Building type & Total in Gundinci & Included in research & Coverage rate \\
\hline Household & 363 & 7 & $2 \%$ \\
Family farm & 300 & 36 & $12 \%$ \\
Big farms & 43 & 33 & $77 \%$ \\
Small farms & 257 & 3 & $1 \%$ \\
Public buildings & 5 & 5 & $100 \%$ \\
Other & 3 & 0 & $0 \%$ \\
\hline
\end{tabular}

Finally, the farms biogas potential was determined using the following equations:

$$
\begin{gathered}
B Y_{F M}=1 \times\left(D M_{F} \times o D M_{F} \times\left(B_{o D M} \times 1,000\right)\right) \times M_{S} \\
B P_{F}=Q_{L U} \times Q_{M} \times B Y_{F M} \times M_{E P}
\end{gathered}
$$

where $B Y_{F M}$, biogas yield per tonne of fresh matter $\left(\mathrm{m}^{3} \mathrm{CH}_{4} / \mathrm{t}\right) ; D M_{F}$, dry matter content, $o D M_{F}$, organic dry matter (\% of $\left.D M_{F}\right) ; B_{o D M}$, biogas yield per tonne of organic dry matter $\left(\mathrm{m}^{3} / \mathrm{kg}_{o D M}\right) ; M_{S}$, share of methane in biogas $(\%) ; B P_{F}$, farm biogas potential (kWh/a); $Q_{L U}$, number of livestock units on farm; $Q_{M}$, manure produced by one livestock unit (t/year); $M_{E P}$, methane energy potential $\left(\mathrm{kW}_{\mathrm{th}} / \mathrm{m}^{3}\right)$, assumed to be $10 \mathrm{~kW}$ th $/ \mathrm{m}^{3}$.

The feedstock characteristics - dry matter content, organic dry matter content, biogas yields and share of methane - were derived from the Kuratorium für Technik und Bauwesen in der Landwirtschaft (KTBL) biogas calculator [14]. Apart from calculating the energy potential for every farm, this was also aggregated for the entire feedstock quantity surveyed (see Figure 2).

In the second step, the farmer's biogas potentials were qualified with his capacity to innovate and cooperate. The capacity to innovate is based on the farmer's development in terms of number of animals and cultivated land over time and future ambitions regarding his/her business goals.

Here two types of data were used - the first compares present animal and land holdings, with values five years ago, while the second indicates the farmer's expectations and ambitions in the next five years. While this can be considered as speculative data, it is useful to know if a famer expects to expand or close down her/his business, especially if the biogas potential is high, meaning that the deficit of her/his feedstock could imperil the normal functioning of a biogas plant.

Moreover, the share of own land and manure management system quality indicates the extent of investments made in their business. The farms that grew in comparison to past five years and had clear development ambitions and had invested in land and manure management are regarded as farms with high innovative capacity. On the other hand, the farmers capacity to cooperate is based on their willingness to supply manure, grow energy crops and invest in the project. This evaluates their willingness to support a local biogas project. 


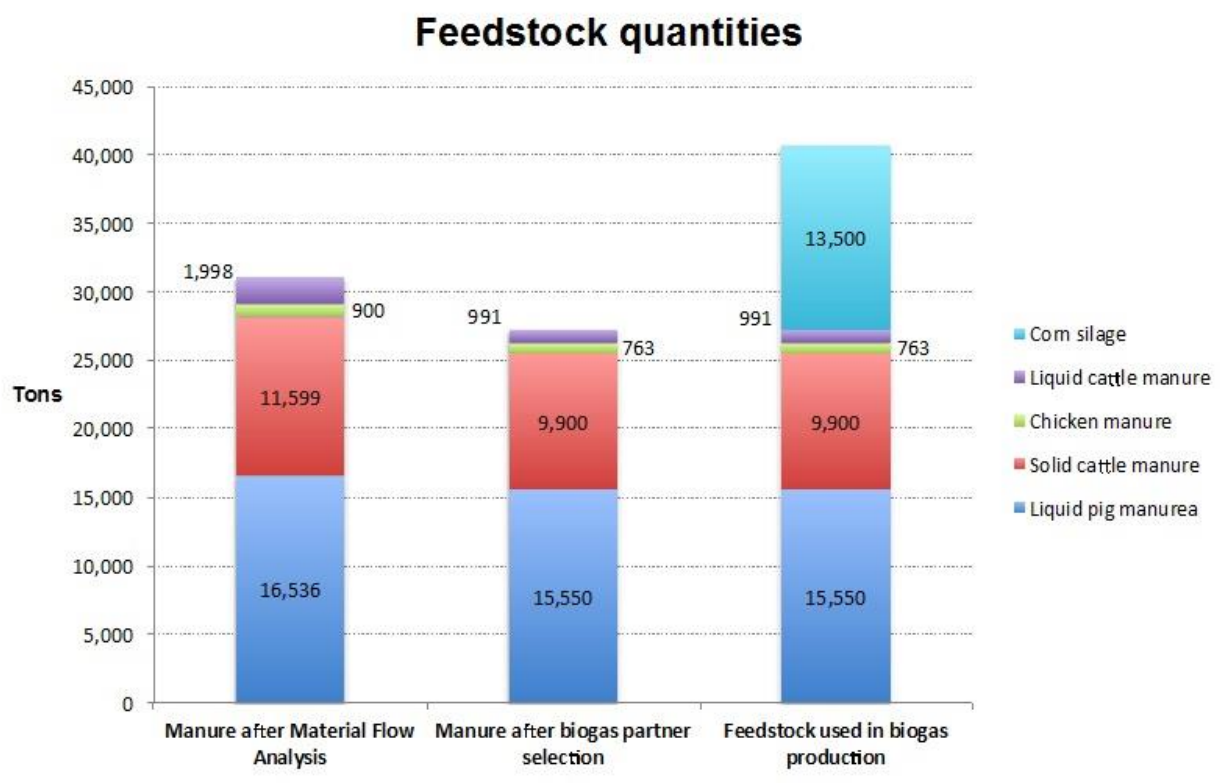

Figure 2. Material flow analysis results and biogas feedstock mixture

The application of the innovative-cooperation methodological approach eliminates from the biogas potentials analysis, those farmers who are unwilling to cooperate and incapable or unwilling to innovate their production process. This is achieved using a biogas partner selection tool. The method develops three indicators named Biogas Potential, Cooperation Capacity and Innovative Capacity - which are given different weights depending on their importance and these are 40\%, 30\% and 30\% respectively. Biogas Potential was given a higher weight because in our assessment the availability of local feedstock constitutes the most important aspect of developing a biogas project. These weights are discussable and could be adjusted in future research.

Each indicator is composed from a subset of variables examined by the structured interviews (see Figure 1). Assigning different points distinguishes the variables weights within an indicator. After allocating the points to each variable and summing them up, a final grade is assigned. This is expressed as the percentage of the total possible points. The farmers that have failed to achieve more than $50 \%$ of the points are excluded from further examination.

Biogas Potential is determined through the energy value of manure and size of land that could be devoted for energy crop growth and this was graded based on norm-referenced grading. Using this method the entire sample sets the standard to which an individual farmer is compared, meaning that an individual farmer is benchmarked in relation to her/his peers.

Innovative Capacity grades the farmers based on the change in number of animals and land under cultivation in comparison to last five years, future ambition and goals, share of own land and manure system quality. The farmers that have increased the number of animals and land under cultivation in the last five years, have clear and positive future goals, own most of the land they cultivate (in comparison to leasing it, which would indicate a risk factor in their ability to grow energy crops) and have manure management systems in line with the European Union Nitrates Directive have received the most points.

Finally, the farmers that would willingly supply their manure, grow energy crops and invest jointly in the plant are regarded as having the highest Cooperation Capacity (see Appendix for results and grading method of the biogas partner selection tool). 
In the third step, the remaining manure quantities are used to calculate the biogas plant installed capacity, which is then analysed in terms of economic feasibility, using cash flow analysis. Apart from manure, corn silage would be added to the feedstock mix due to its higher energy density, which increases the economics of a plant.

Asking the farmers the total land area they cultivate and how much they could allocate for energy crop growth estimated the land availability for energy crops. In total the farmers said they could allocate 433 ha of land for this purpose.

Corn silage was selected based on a study of most suitable energy crops for biogas production. The study compares sunflower, Jerusalem artichoke, sorghum, sugar beets, amaranth and maize from an environmental, technical and economic perspective [15] and concludes maize has the best overall characteristics (corn silage being a product of maize cultivation). Apart from this, maize is traditionally grown in the region and our research indicates it's the most cultivated crop in Gundinci.

The overall installed capacity of the plant was derived in two steps. First we calculated the theoretical installed capacity, based on the available energy potential of the feedstock.

The theoretical capacity was derived in the following way:

$$
\begin{gathered}
I C=\frac{G E P_{\text {total }}}{L_{f}} \\
G E P_{\text {total }}=\sum B P_{F}
\end{gathered}
$$

The electrical and thermal capacities were obtained through applying the following:

$$
\begin{aligned}
& I C_{e l}=I C \times \eta_{e l} \\
& I C_{t h}=I C \times \eta_{t h}
\end{aligned}
$$

The theoretical capacity is just an estimate of the potential size a project could have, and it is based on the energy value of feedstock. However, this is also a starting point to determine the actual project size. Therefore, we conducted interviews with two biogas project developers to determine the real installed capacity and investment costs we would base our economic analysis on. They also consulted us on the optimal feedstock mixture, based on its energy value, nutrient and dry matter content. Also we interviewed them on technologies for producing pellets and organic fertilizer from biogas digestate, including their costs and production quantities.

Apart from electricity, which the project would sell under the current feed-in tariff law in Croatia [16], pellets also constitute part of the revenue. These are made from the anaerobic digestion remains (digestate) and waste sawdust. Heat from the biogas plant is used in drying one portion of the digestate $(45 \%)$ and preparing it for pellets production, while the other part would be given back to farmers as organic fertilizer (55\%).

\section{RESULTS}

The research collected data through 43 structured interviews with owners of local family farms and households in Gundinci. Our survey found 31,000 t of usable manure from different husbandry operations, with an approximate technical energy potential of 6.5 GWh, which is double the yearly electricity consumption in Gundinci [17]. 
Furthermore, we determined that the farmers operate 393 ha of land which could be used for growing energy crops, since it is not currently in use for growing animal feed for their own farms. In our analysis we did not determine the potential energy value of energy crops that could be grown on that same land, because these are not a waste flow and were not within the scope of our analysis.

Our methodology develops a grading mechanism that evaluates farmers in terms of their biogas potential and innovative-cooperation capacity. Using this method we were able to exclude from further analysis those farms, which are stagnating and lack willingness to provide biogas feedstock or support a biogas project financially. As a result we excluded from detailed analysis approximately $15 \%$ of the originally located biogas potential, which can be seen in Figure 2. Considering the traditional experience in producing corn silage in the region and literature review [15] we decided to add 13,500 $\mathrm{t}$ to our biogas mixture. The final mixture then constitutes of $33 \%$ corn silage and $67 \%$ manure, where corn silage yields $70 \%$ of the final energy content.

After qualifying the farmers based on their innovative-cooperation capacity we calculated the theoretical installed capacity using eq. (3) and eq. (4), after which we derived the electrical and thermal theoretical capacities using eq. (5) and eq. (6). These are $1,223 \mathrm{~kW}_{\mathrm{el}}$ and $1,112 \mathrm{~kW}_{\mathrm{th}}$. Based on this we asked a project developer to determine the real capacity, according to industry Combined Heat and Power (CHP) engine unit size. After consultations, our analysis continued with a real electrical capacity of 1,250 $\mathrm{kW}_{\mathrm{el}}$.

Our analysis indicates the project would have equity IRR of $16 \%$. The biogas hurdle rate in Croatia is $8 \%[18,19]$, making this project very attractive for investors. In our analysis we used input variables that are presented in Figure 3. The main revenue streams of this project are electricity sales under the Croatian Feed-in Tariff (FIT) system and pellets, which are produced from remaining solid digestate and saw dust.

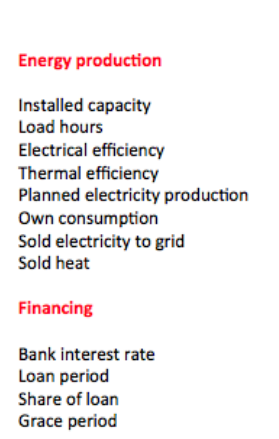

Equity IRR = 16\%

Revenues structure (EUR)

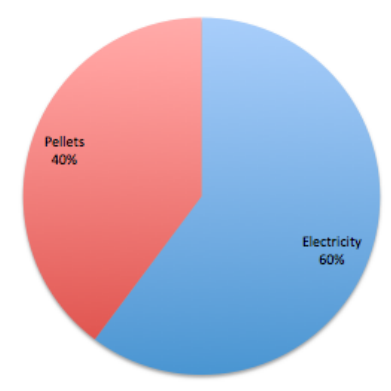

MAIN MODEL PARAMETERS

$\begin{array}{ll}\mathrm{kW} & 1,250 \\ \mathrm{~h} & 8,000 \\ \% & 44 \\ \% & 40 \\ \mathrm{kWh} & 10,000,000 \\ \mathrm{kWh} & 1,256,000 \\ \mathrm{kWh} / \mathrm{a} & 8,744,000 \\ \mathrm{kWh} & 0 \\ & \\ & \\ \% & 12 \\ \text { year } & 10 \\ \% & 70 \\ \text { year } & 1\end{array}$

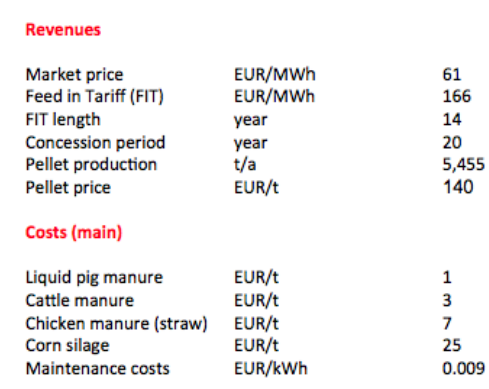

Investment costs $=5,500 \mathrm{EUR} / \mathrm{kW}$

Operating costs structure

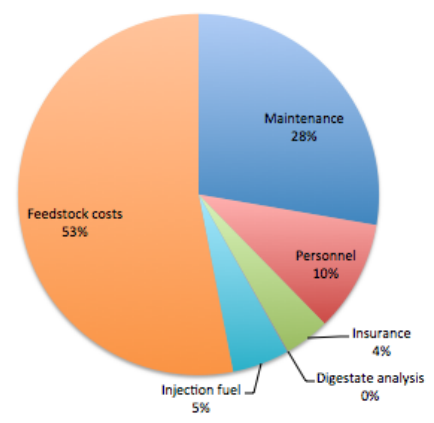

Figure 3. Main input variables, results, revenues and operational costs 
Producing and selling pellets has several benefits, the most prominent one being use of heat. Biogas projects in Croatia receive support only if they convert more than $50 \%$ of used primary energy into useful electricity and heat [16]. Through producing pellets, our project would have an estimated overall efficiency of 67\%. Apart from this, with a market price of $140 \mathrm{EUR} / \mathrm{t}$ - determined through consultations with industry experts pellets are very profitable and in this case yield $40 \%$ of the project's revenues.

Finally, we conducted a sensitivity analysis to determine the effects of changing market conditions on the project's IRR. Our analysis shows that the project is mostly sensitive to changes in investment costs and feed-in tariff, followed by pellets and corn silage price, in order of magnitude (Figure 4).

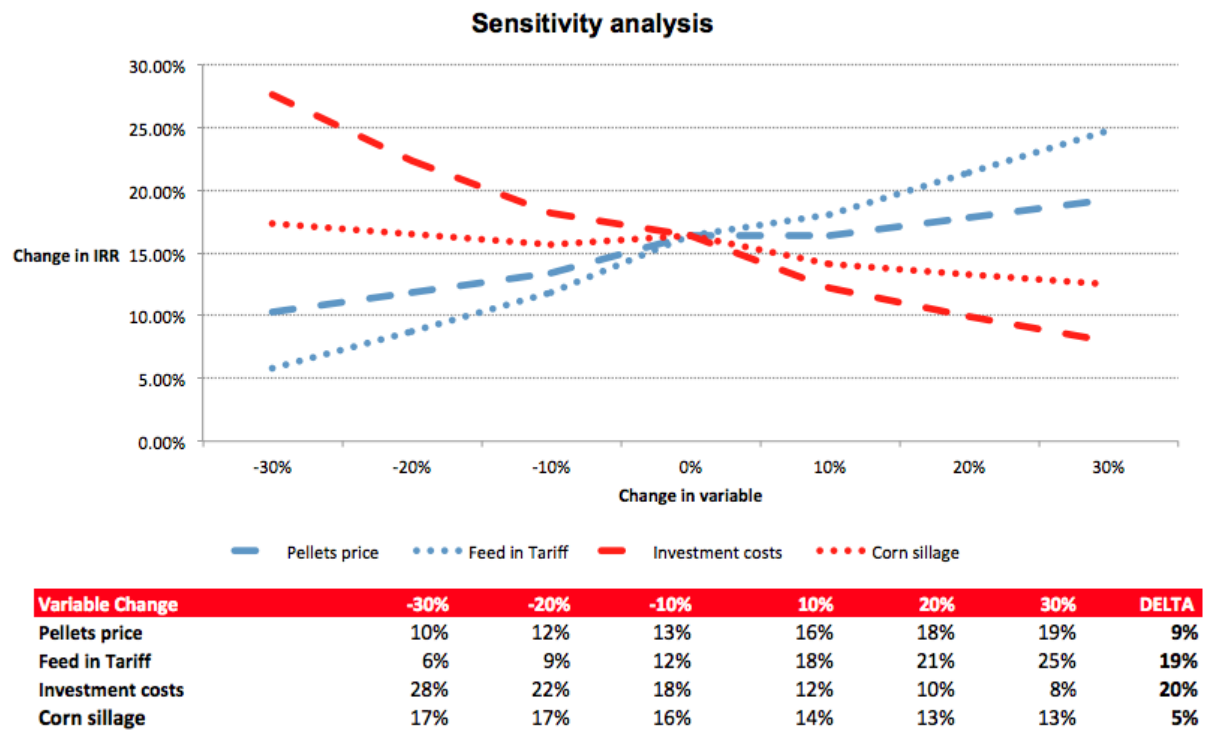

Figure 4. Project sensitivity analysis

\section{CONCLUSIONS}

We explained and empirically tested the bottom-up approach with the aim of evaluating the biogas potential of Gundinci municipality in Brodsko-Posavska County in the region of Slavonia. We found that the bottom-up approach has advantages compared to the conventional (top down) approach. It embraces complexity, decision-making is based on location specific material and energy flows and it calculates the biogas potential based on feedstock from farmers with innovative cooperation potential.

This methodology determines the suitability of any location for developing a biogas project, based on analysis of the following aspects:

- Local material and energy flows;

- Farmers innovative-cooperation capacity;

- Economic and technical feasibility of the project.

Using this methodology reveals local biogas potentials and empowers local communities to start a biogas project. This is achieved by improving their knowledge on local material and energy flows and project costs. Knowing this enables them to make first contact with project developers, investors and funding institutions. Alternatively, this also enables biogas project developers to focus on locations with sufficient biogas potential and communities that are willing to innovate and cooperate.

The replication of this methodology could pinpoint locations in Croatia with substantial biogas potential. Instead of relying on statistics, we propose conducting such bottom-up research to determine real projects. But apart from this, we consider that 
analysing the human aspect of developing such projects i.e. the willingness of local population to accept it and help it succeed (through supplying manure for instance) is also vital. This is why we have introduced the innovative-cooperation potentials as a decision-making criterion.

An interesting topic for further research would be discussing ownership models of communal biogas plants, which can be either third party or community owned [20]. Combinations of these are also possible, in the case of partnerships between the community and an outside investor. However, more benefits for the locals are achieved if the project is in their ownership. This would require a high degree of self-organization, which could be achieved through forming energy cooperatives.

Finaly the analysis of formal and informal institutions such as social, cultural and legal norms which underline economic activities will be required in the future. Doing so could underline many incentives and constraints that form economic behaviour in connection with developing a biogas project in a community.

\section{NOMENCLATURE}

$\begin{array}{llc}B Y_{F M} & \text { Biogas yield per tonne of fresh matter } & {\left[\mathrm{m}^{3} \mathrm{CH}_{4} / \mathrm{t}\right]} \\ B_{o D M} & \text { Biogas yield per tonne of organic dry matter } & {\left[\mathrm{m}^{3} \mathrm{~kg}_{\mathrm{oDM}}\right]} \\ B P_{F} & \text { Farm biogas potential } & {[\mathrm{kWh} / \mathrm{a}]} \\ D M_{F} & \text { Dry matter content } & {[\%]} \\ o D M_{F} & \text { Organic dry matter content } & {[\%]} \\ I C & \text { Installed capacity } & {[\mathrm{kW}]} \\ I C_{e l} & \text { Installed electrical capacity } & {\left[\mathrm{kW}_{\mathrm{el}}\right]} \\ I C_{t h} & \text { Installed thermal capacity } & {[\mathrm{kW} \text { th }]} \\ I R R & \text { Internal rate of return } & {[\%]} \\ \eta_{e l} & \text { Electrical efficiency } & {[\%]} \\ \eta_{t h} & \text { Thermal efficiency } & {[\%]} \\ G E P_{\text {total }} & \text { Total gross energy potential } & {[\mathrm{kW}]} \\ L U & \text { Livestock units } & {[\mathrm{kg}]} \\ L_{f} & \text { Load factor } & {[-]} \\ M_{S} & \text { Share of methane in biogas } & {[\%]} \\ M_{E P} & \text { Methane energy potential } & {\left[\mathrm{kW} \text { th } / \mathrm{m}^{3}\right]} \\ N P V & \text { Net present value } & {[\%]} \\ Q_{L U} & \text { Number of livestock units on farm } & {[-]} \\ Q_{M} & \text { Manure produced by one livestock unit } & {[\mathrm{t} / \mathrm{year}]}\end{array}$

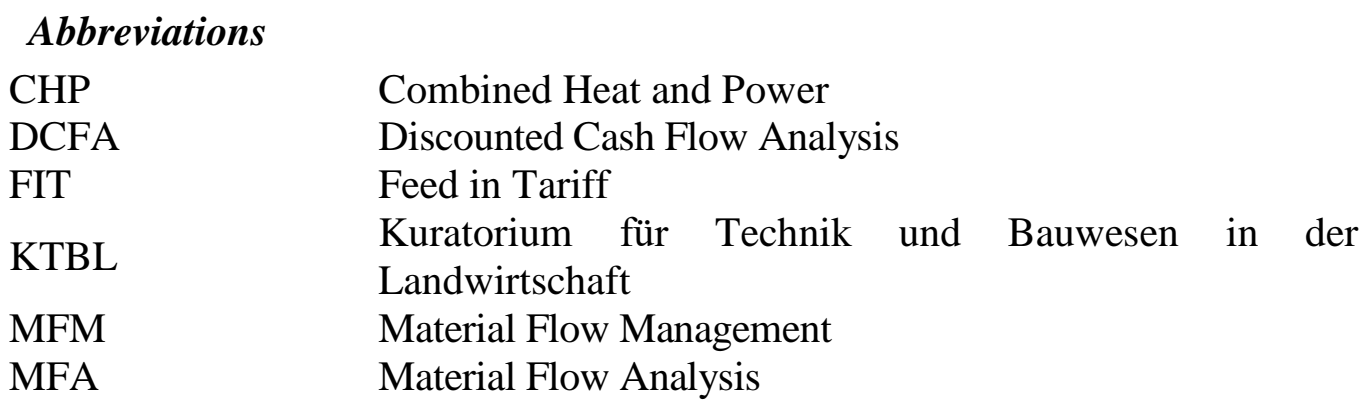

\section{REFERENCES}

1. Kulišič, B. and Par, V., Agricultural Potential for Biogas Production in Croatia, Agriculturae Conspectus Scientificus, Vol. 74, No. 3, pp 215-220, 2009.

2. Kralik, D., Potencijali biogasa u Republici Hrvatskoj, Novi Sad, Serbia, $24^{\text {th }}$ October 2012 
http://www.psemr.vojvodina.gov.rs/index.php/dokumenti/dani-energetike/2012 [Accessed: 17-December-2013]

3. Pukšec, T. and Duić, N., Biogas Potential in Croatian Farming Sector, Strojarstvo, Vol. 52, No. 4, pp 441-448, 2010.

4. Lu, H., Material Flow Management, Compex Systems and China's Circular Economy Strategy, In Forum für angewandtes systemisches Stoffstrommanagement, Institute for Applied Materal Flow Management, Forum für angewandtes systemisches Stoffstrommanagement, Instituts für angewandtes Stoffstrommanagement, Birkenfeld, Germany, e.V., 2005.

5. Ministry of Regional Development and EU Funds, Vrijednost indeksa razvijenosti i pokazatelja za izračun indeksa razvijenosti na lokalnoj razini, 2014, http://www.mrrfeu.hr/default.aspx?id=405 [Accessed: 15-November-2014]

6. Hiremath, R. B., Kumar, B., Balachandra, P. and Ravindranath, N. H., Bottom-up Approach for Decentralised Energy planning: Case Study of Tumkur District in India, Energy Policy, Vol. 38, No. 2, pp 862-874, 2010, http://dx.doi.org/10.1016/j.enpol.2009.10.037

7. Raha, D., Mahanta, P. and Clarke, M. L., The implementation of Decentralised Biogas Plants in Assam, NE India: The Impact and Effectiveness of the National Biogas and Manure Management Programme, Energy Policy, Vol. 68, pp 80-91, 2014, http://dx.doi.org/10.1016/j.enpol.2013.12.048

8. Mallett, A., Social Acceptance of Renewable Energy Innovations: The Role of Technology Cooperation in Urban Mexico, Energy Policy, Vol. 35, pp 2790-2798, 2007, http://dx.doi.org/10.1016/j.enpol.2006.12.008

9. Aralica, Z., Rajh, E. and Redžepagić, D., Istraživanje Inovacijskog Potencijala Mađarsko - Hrvatske Pogranične Regije - Međimurska županija i Koprivničko križevačka županija - Europska Unija - IPA prekogranični program Mađarska Hrvatska, Ekonomski Institut, Zagreb, 2012.

10. Daim, T. U., Aralica, Z., Dabić, M., Özdemir, D. and Bayraktaroglu, E. A., Researching Innovative Capacity of Local Subsidiaries in Selected CEE Countries, Technology Development, Springer International Publishing, pp 277-300, 2014, http://dx.doi.org/10.1007/978-3-319-05651-7_14

11. Gundinci Municiplaity, Plan gospodarenja otpadom općine Gundinci za razdoblje od 2011. do 2019. godine, 2011.

12. Ministry of Agriculture, Pravilnik o dobroj poljoprivrednoj praksi u korištenju gnojiva, 56/08, Narodne Novine, http://narodne- novine.nn.hr/clanci/sluzbeni/ 2008_05_56_1937.html [Accessed: 01-December-2013]

13. Đukan, M. Energy Cooperatives as a New Model for Renewable Energy Development in Croatia: Investigation into Biogas Production from Agricultural Waste in Gundinci Municipality, M.Eng. Thesis, Trier Univeristy of Applied Sciences, Environmental Campus Birkenfeld, 2013.

14. Kuratorium für Technik and Bauwesen in der Landwirtschaft, Wirtschaftlichkeitsrechner Biogas, 2014, http://daten.ktbl.de/biogas/startseite.do, [Accessed: 27-December-2014].

15. Vindiš, P., Muršec, B., Črtomir, R. and Čus, F., A Multi-Criteria Assessment of Energy Crops for Biogas Production, Journal of Mechanical Engineering, Vol. 56, No. 1, pp 63-70 (2009).

16. Vlada Republike Hrvatske, 2013, Tarifni sustav za proizvodnju energije iz obnovljivih izvora energije i kogeneracije, http://narodne-novine.nn.hr/clanci/ sluzbeni/2013_11_133_2888.html, [Accessed: 05-December-2013]

17. HEP - Operater distribucijskog sustava d.o.o. - Elektra Vinkovci, Pregled obračunskih MM s potrošnjom od 0 do 10000000 kWh - Kućanstvo, 2012. 
18. Hahn, H., Smjernice za financiranje poljoprivrednih bioplinskih postrojenja: Edukacijski materijal za investitore u bioplin (mimeo), D.3.8.2, WP 3, Fraunhofer IWES, IEE Project BiogasIN, 2011.

19. Metzler, R. and B. K., Bioplinska postrojenja na stočarskim farmama Hrvatske: procjena potencijalnog tržišta i potrebnog financiranja, Programme for the Promotion of Energy Efficiency and Renewable Energies in Croatia, 2012.

20. Pukšec, T., and Duić, N., Economic Viability and Geographic Distribution of Centralized Biogas Plants: Case Study Croatia, Clean Technologies and Environmental Policy, Vol. 14, No. 3, pp 427-433, 2012, http://dx.doi.org/10.1007/s10098-012-0460-y

\section{APPENDIX}

Biogas partner selection tool results

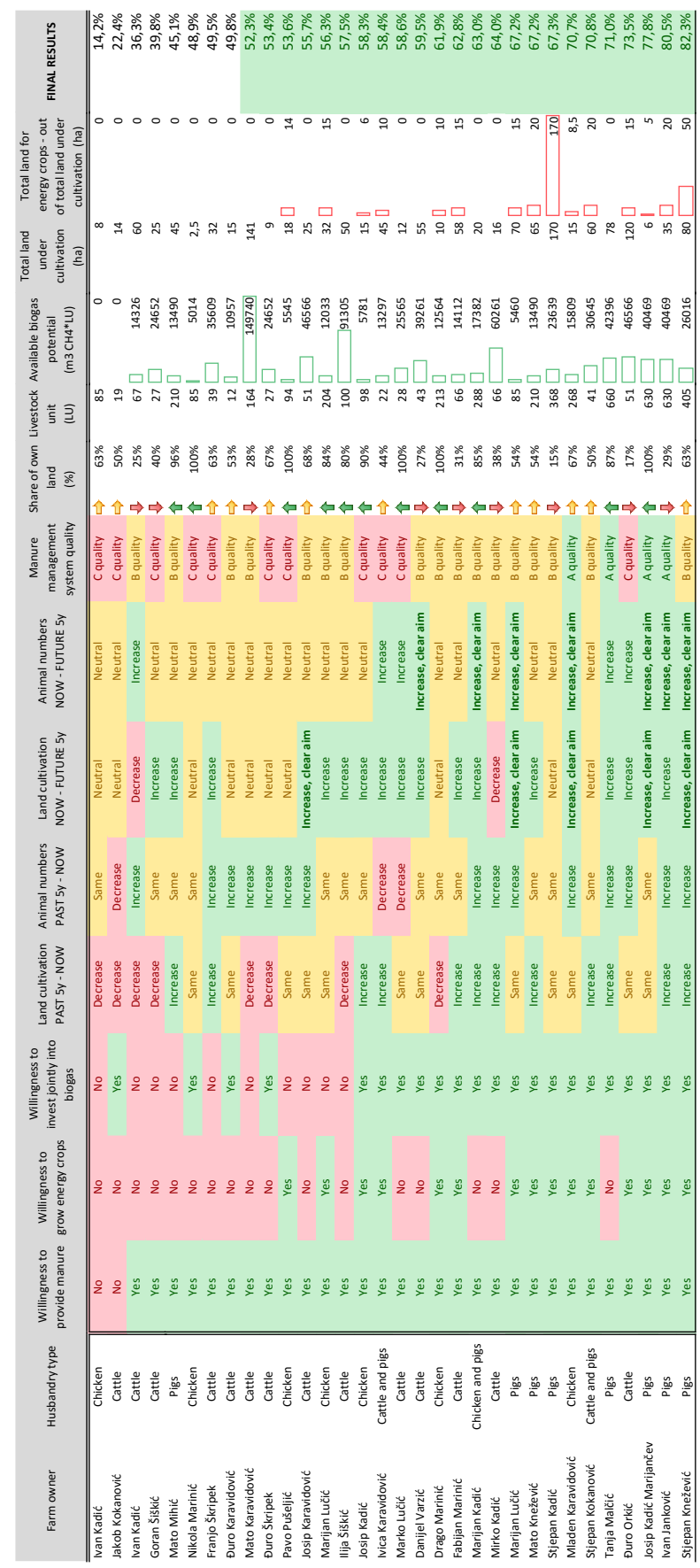


Biogas partner selection tool results grading methodology

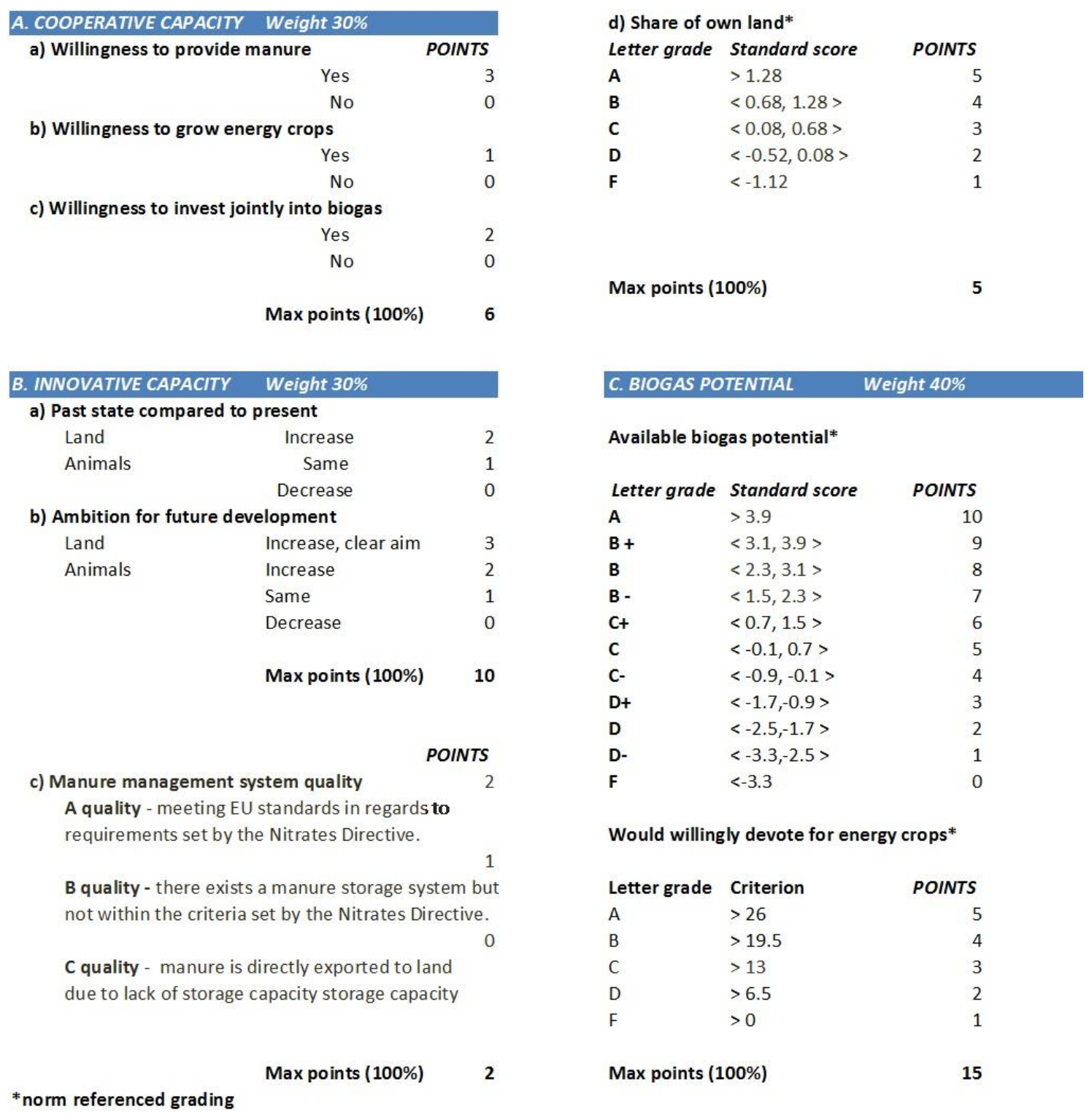

Paper submitted: 01.12.2014

Paper revised: 06.01.2015

Paper accepted: 08.01.2015 